\title{
An Investigation of the Relationship between Prospective teachers' Self-Efficacy Beliefs and their Attitudes towards Teaching Profession
}

\author{
Öznur ATAŞ AKDEMİR ${ }^{1}$ \\ 'PhD Faculty Member, Frrat University, Faculty of Education, Elazı̆̆, Turkey
}

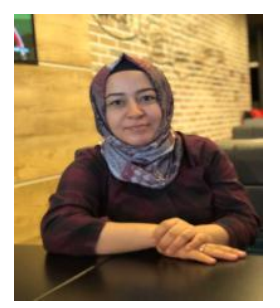

\begin{abstract}
The purpose of this research is to determine the relationship between prospective teachers' selfefficacy beliefs and their attitudes towards the teaching profession. Correlational research model was used in this research. 312 students studying in different departments of Ağrı İbrahim Çeçen University Faculty of Education participated in the research. The research data were collected by the Teacher Self-efficacy Beliefs Scale and Attitude Scale towards Teaching Profession. In the analysis of the data, arithmetic mean, standard deviation, Pearson product moment correlation analysis and multiple regression analysis methods were applied. The results of the analysis revealed that the self-efficacy beliefs of the prospective teachers were at the level of definitely believing and attitudes towards the teaching profession were mostly in agreement. Prospective teachers were found to have higher self-efficacy beliefs in terms of positive classroom environment and lower self-efficacy belief in academic development. There was a significant positive correlation between the self-efficacy beliefs of prospective teachers and their attitudes towards the teaching profession. Furthermore, it has been reached as a result that the planning and learning development dimension of self-efficacy beliefs is a significant predictor of prospective teachers' attitudes towards the teaching profession.
\end{abstract}

Keywords: Self-efficacy, Attitude towards teaching profession, Prospective teachers.

Citation | Öznur ATAȘ AKDEMİR (2018). An Investigation of the Relationship between Prospective teachers' Self-Efficacy Beliefs and their Attitudes towards Teaching Profession. Journal of Education and e-Learning Research, 5(3): 157-164.

History:

Received: 12 March 2018

Revised: 26 June 2018

Accepted: 3 August 2018

Published: 9 October 2018

Licensed: This work is licensed under a Creative Commons

Attribution 3.0 License (cc) EY

Publisher: Asian Online Journal Publishing Group
Funding: This study received no specific financial support.

Competing Interests: The author declares that there are no conflicts of interests regarding the publication of this paper.

Transparency: The author confirms that the manuscript is an honest, accurate, and transparent account of the study was reported; that no vital features of the study have been omitted; and that any discrepancies from the study as planned have been explained.

Ethical: This study follows all ethical practices during writing.

\section{Contents}

1. Introduction

2. Method.

3. Findings 


\section{Introduction}

As the world encounters differences in several issues, the qualities that individuals must possess also changes. It is possible that educational institutions can acquire the qualities that individuals desire, by operating all parts of education system appropriately. Teacher, student, manager, supervisor, school, environment and family constitute these parts. Teacher plays a major role in ensuring that the education system which consists of these parts is qualified and productive. Teachers are giving new behaviors to students through the education programs. Depending on the characteristics of these behaviors, teachers should develop the professional knowledge and skills they should possess (Kahyaoglu and Yangin, 2007; Şahin, 2010). The prospective teachers receive during the nomination period is of great importance in the formation and development of these skills. Prospective teachers' personal perceptions and judgments in terms of professional knowledge, skills and experiences play an active role in overcoming the pedagogical difficulties they will face in their professional lives. Self-efficacy beliefs are defined by concept of prospective teachers' sense of self-efficacy in terms of professional knowledge and skills (Özdemir, 2008).

One of the most significant current discussions in educational sciences is prospective teachers' self-efficacy beliefs (Celep, 2000; Aşkar and Umay, 2001; Savran and Çakıroğlu, 2001; Akkoyunlu and Kurbanoglu, 2003; Morgil et al., 2004; Altuncekic et al., 2005; Çakiroglu et al., 2005; Akbas and Çelikkaleli, 2006; Özenoğlu-Kiremit, 2006; Ready-Bıkmaz, 2006; True et al., 2006; Usluel, 2006; Özbek et al., 2007; Eryenen, 2008; Özdemir, 2008; Öksüzoğlu, 2009; Azar, 2010; Gürol et al., 2010; Şahin and Hciomeroglu, 2010; Külekçi, 2011; Smolleck and Mongan, 2011; Aksou et al., 2012; Lin and Liang, 2012; Oğuz, 2012; Soprano and Yang, 2012; Ülper and Bağcl, 2012). It has been seen that most studies conducted on this topic have only been carried out in special content knowledge competencies such as science, biology, mathematics, computer. Few studies have been conducted on prospective teachers' self-efficacy beliefs (Ekici, 2008; Uysal and Kösemen, 2013). Thus, it is thought that there is a need for more studies conducted on prospective teachers' self-efficacy beliefs.

Recent researches have find out that there are some certain factors that affect self-efficacy beliefs. These factors are academic achievement (Eryenen, 2008; Yilmaz et al., 2012; Dennis, 2013; Owens-Twaites, 2013) hope and anxiety (Kemer, 2006) epistemological beliefs (Gürol et al., 2010) and life purposes (Aydıner, 2011). Additionaly, recent studies (Çakır et al., 2006; Çapri and Çelikkaleli, 2008; Çaycı, 2011; Demirtas et al., 2011; Kutlu and Gökdere, 2012) have showed that there is a relationship between self-efficacy beliefs and attitudes towards the teaching profession. However, these recent studies have paid their attention to determine the level of the relationship between these variables but they haven't paid any attention to determine the strength of the relationship. In other words, no previous study has investigated the topic. Therefore, this study aims at finding out the level and strength of the relationship between self-efficacy beliefs and attitudes towards the teaching profession which are key concepts affecting the teachers' quality in the educational sciences.

\subsection{Self-Efficacy Beliefs}

Self-efficacy belief is one of the concept that Albert Bandura highlights as a foundation for his Social Learning Theory (1982). According to Bandura, self-efficacy belief is related to competence or chances of successfully accomplishing a task that is needed to overcome the contingencies.

No matter how wrong or right are these beliefs, they affect the choices of activities and regulation of environment. People avoid carrying out duties which they believe that these duties place great demands on them but the ones who can judge their management competence perform and achieve these duties.

Self-efficacy belief is not a fixed notion or simply knowing what to do. Self-efficacy belief includes productive capacity including social, cognitive, behavioural abilities, which must be organized to serve numerous purposes. Self-efficacy belief also determines how hard they try and how long they stand against difficulties. If the person has worries about his/her capacity in difficult times, he/she can decrease his/her efforts and give up performing the task. On the other hand, person who has absolute confidence in his/her capacity try hard when he/she face with difficulties and he/she can be more ambiguous to cope with these difficulties (Bandura, 1982). Also, self-efficacy does not mean being talented but it means the belief that people belive in their own resources. A talented person who faces with difficulties can not use his/her abilities if he/she has a low sense of efficacy. Person with high efficacy beliefs attributes failure to choosing wrong methods and strategies rather than his/her own deficiencies. High self-efficacy brings beliefs personal development, success, various skills and well-being in its wake (Yildirim and İlhan, 2010). According to Özdemir (2008) teachers' and prospective teachers' self-efficacy belief related to teaching process is one of the important factors that gives them a hand to solve the problem related to classroom management, plan, apply and assess the teaching process, make students successful and motivated.

According to Bandura (1997) self-efficacy belief has an important role in life and it depends on four sources that are interrelated. These sources can be summarized as follows:

1)Mastery experiences: Performing a task successfully can be counted as a reward for a person and it affects his performance of the following task in a positive way. Additionally, these experiences are directly related to his own experiences.

2)Emotional states: The emotional and physicological state a person is in affects the possibilty of commiting to perform the task.

3)Vicarious experience: Observing the other people's success has a positive effect on a person's belief related to be his/her own success.

4) Verbal persuasion: When other people encourage and convince a person to perform a task, this person tend to believe that he/she is able to perform the task and it also increases his/her sense of self-efficacy.

The sources which are mentioned above contribute to the development of self-efficacy beliefs. These sources have both positive and negative effects on development of self-efficacy beliefs in people's life. For example, when the people observe the others' failure as vicarious experience, it makes the person believe that he/she will fail. 


\subsection{Attitude towards Teaching Profession}

Teacher as one of the key elements of education system takes important responsibility of educating qualified people according to the neccessities of the time. In order to fullfill these responsbilities and increase the quality of education system, teachers should have positive attitude towards teaching profession before starting their professional career and they should have affective domain competency (Karadağ, 2012).

Attitude can be defined as complex mental state including personal behaviours. Attitude towards profession means people's emotion, behaviours and vocational commitment related to their own professions (Hussain et al., 2011). Teachers' attitude towards teaching profession is related to their belief that they should love their professions, commit themselves to it, have awareness of their professions' necessity and importance for the society and constantly develop themselves by force of their professions. Positive or negative attitudes towards these topics have important effects on prospective teachers' code of professional conduct. For this reason, students' leaming experiences, should be organized in a way that make them have positive attidutes towards teaching profession (Coşkun, 2011; Özkan, 2012). If a teacher who has positive attitude towards teaching profession is committed to his/her profession, performance of this teacher will be better; and s/he will be more productive (Hussain et al., 2011). In this context, prospective teachers who get down to teaching profession have positive attitude towards teaching, positive values and perceptions which can be seen as determinant of the success in their professional life (Karadağ, 2012). During the vocational education, people get trained to determine their vocational behaviours related to their future professions. Vocational behaviours of the teachers can be more effective by the help of the emotion, information, and skills that are aimed to be teach to the students in teacher training programs. If the prospective teachers want to do what is necessary for their profession and be successful in their professional life, they should have positive attitude towards teaching profession. These positive attitudes direct the prospective teachers' expactations related to their professions and increase their motivation. Additionally, it helps prospective teachers learn knowledge, skills and values related to teaching professions (Üstüner, 2006; Karadağ, 2012).

There are some studies conducted on the prospective teachers' attitudes towards teaching professions with the participation of prospective teachers from different fields (Aşkar and Erden, 1986; Gürbüztürk and Genç, 2004; Oral, 2004; Saban et al., 2004; Işık et al., 2005; Kaya and Büyükkasap, 2005; Akpinar et al., 2006; Aslan and Ayol, 2006; Bulut and Doğar, 2006; Kahyaoglu and Yangin, 2007; Tanel et al., 2007; Baykara-Pehlivan, 2008; Bedel, 2008; Çapri and Çelikkaleli, 2008; Oguz and Topkaya, 2008; Temizkan, 2008; Bulut, 2009; Çetinkaya, 2009; Üstüner et al., 2009; Can, 2010; Coşkun, 2011; Tekerek and Polat, 2011; Bektaş and Nalçacı, 2012; Karadağ, 2012; Open and Kolomuç, 2012; Caglar, 2013). These studies reveal that prospective teachers have positive attitudes towards teaching profession.

Some of the studies conducted on the prospective teachers' attitudes towards teaching profession reveal that prospective teachers do not have positive attitudes towards teaching profession (Osunde and Izevbigie, 2006; Hussain et al., 2011; Kahyaoğlu et al., 2013). In the research which (Osunde and Izevbigie, 2006) conducted in Nigeria with the participation of 400 middle-school teachers revealed that irregularity in wage (delay in payment of wages), low wage, weak physical environment, despair in promotion and recession affect the teachers' attitude towards their own profession.

In Hussain et al. (2011) which examined 120 middle-school teachers' attitude towards their profession, it was found that most of the teachers don't have positive attitude towards their own professions, and female teachers have more positive attitude towards their professions when compared with male teachers. Also, they reveal that teachers who work in public shools are more committed to their professions when compared with the teachers who work in private schools. Similarly, teachers who work in rural areas are more committed to teaching professions when compared with the teachers who work in urban. In their studies conducted on prospective teachers' learning styles and attitudes towards teaching professions, Kahyaoğlu et al. (2013) find that prospective teachers' attitudes towards their profession are in the low degree. The main reason of that situation is that prospective teachers who prefer this profession are averse to teaching profession or they prefer it without knowing it exactly.

It is pointless to expect that a pre-service teacher who has low self-efficacy related to necessities cannot try hard to be successful in their teaching profession. In parallel with it, a pre-service teacher who has low self-efficacy can't develop a positive attitude towards the teaching profession. For this reason, the courses which taken by prospective teachers should include courses that enable them develop positive attitude towards the teaching profession and reach professional competence. It can be said that prospective teachers who have positive attitudes towards their profession will love teaching profession and try to fulfill the necessities of this profession (Demirtas $e t$ al., 2011). It can be claimed that prospective teachers who have positive attitudes towards their profession and high self-efficacy will make important contributions to education system of their country.

The present research is conducted to determine the relationship between teacher self-efficacy beliefs of the prospective teachers and their attitudes towards the teaching profession. This research aimed at seeking answers to the following research questions:

1.What are prospective teachers' self-efficacy beliefs and attitudes towards the teaching profession?

2.Is there a significant relationship between the self-efficacy beliefs perceived by prospective teachers and the attitude towards the teaching profession?

3.Are the dimensions of self-efficacy beliefs of prospective teachers a significant predictor of their planning and learning development, positive classroom setting, effective learning-teaching process, perceptions of individual differences and academic development, attitudes towards the teaching profession?

\section{Method}

\subsection{Research Model}

The present research is designed in a correlational survey model to determine the relationship between prospective teachers' self-efficacy beliefs and their attitudes towards the teaching profession. 


\subsection{Participants}

The study was conducted in the fall semester of 2017-2018 academic year, with 312 prospective teachers who study in different departments of A $\breve{g r}$ İbrahim Çeçen University Faculty of Education. Of all the prospective teachers who participated in the study $210(67.3 \%)$ prospective teachers are female and $120(32.7 \%)$ prospective teachers are male. When the prospective teachers' distribution are analyzed according to the department of them, it is seen that there are 59 prospective teachers $(18.9 \%)$ who study in the Department of Elementary School Mathematics Teaching, 25 prospective teachers $(8.0 \%)$ studying in the Department of Fine Arts Teaching, 54 prospective teachers $(17.3 \%)$ studying in the Department of Psychological Counseling and Guidance, 63 prospective teachers $(20.2 \%)$ studying in the Department of Elementary Education, 59 prospective teachers (18.9 $\%)$ studying in the Department of Social Sciences Teaching, 52 prospective teachers $(16.7 \%)$ studying in the Department of Turkish Language Teaching.

\subsection{Data Collection Tools}

In the present research, "Teacher Self-Efficacy Beliefs Scale" (TSEBS) developed by Dellinger et al. (2008) and adapted to Turkish by Taskin and Hciomeroglu (2010) and "Attitude towards Teaching Profession Scale" (ATPS) developed by Üstüner (2006) are used as data collection tools. Teacher Self-Efficacy Beliefs Scale (TSEBS) is composed of 29 items with four Likert-type grades and five dimensions namely planning and enhancing learning, creating positive classroom setting, effective learning-teaching process, individual differences and academic development. The articles in the scale organized as, (1) "don't believe", (2) "belive to some degree", (3) "believe", (4) "absolutely believe". In the exploratory factor analysis made by Taskin and Hciomeroglu (2010) to determine the construct validity of the scale, it is stated that all the dimensions represents $56.66 \%$ of total variance.

In the reliability analysis conducted by Taskin and Hciomeroglu (2010) the Cronbach alpha reliability coefficient was found 0.95 , the Cronbach alpha reliability that belongs to dimensions were 0.89 for planning and enhancing learning, 0.86 for positive classroom setting, 0.84 for effective learning teaching, 0.78 for individual differences and 0.73 for academic achievement. On the other hand, in the reliability analysis conducted by the researchers, the Cronbach alpha reliability coefficient was 0.96, the Cronbach alpha reliability coefficients were 0.88 for planning and enhancing learning, 0.89 for creating positive classroom setting, 0.85 for effective learning teaching process, 0.74 for individual differences and 0.79 for academic achievement.

"Attitude towards Teaching Profession Scale" (ATPS), a five-point Likert-type scale, has 34 items in one-dimensional measure construct. The articles in the scale organized as, (1) "absolutely disagree", (2) "partly agree", (3) "agree to some degree", (4) "mostly agree" (5) "absolutely agree". In the exploratory factor analysis conducted to determine the construct validity of the scale, the variance of the scale is determined as $30 \%$. In the reliability analysis made by Üstüner (2006) the Cronbach alpha reliability coefficient is determined as 0.93. Similarly, in the reliability analysis conducted by the researchers, the Cronbach alpha reliability coefficient is determined as 0.94

\subsection{Data Analysis}

Statistical analysis of the data is conducted by SPSS. The Pearson product moment correlation analysis is used to determine the relationships between these dimensions and the arithmetic mean, standard deviation analysis to determine the attitudes of prospective teachers to the self-efficacy beliefs and teaching profession, and multiple regression analysis is used to investigate the predictive attitudes of prospective teachers towards self-efficacy beliefs. Taskin and Hciomeroglu (2010) determine the score intervals of "Teacher Self-Efficacy Beliefs Scale" (TSEBS) as follows: 1.00-1.75 Don't believe; 1.76-2.50 "Belive to some degree"; 2.51-3.25 "Believe"; 3.26-4.00 "Absolutely believe". On the other hand, Üstüner (2006) uses following score intervals to interpret and grade the weighted mean scores gathered from "Attitude towards Teaching Profession Scale" (ATPS): 1.00-1.79 "Absolutely disagree"; 1.80-2.59 "Partly agree"; 2.60-3.39 "Agree to some degree"; 3.40-4.19 "Mostly agree" ; 4.20-5.00 "Absolutely agree".

\section{Findings}

Results of the analysis of data gathered in the study are presented in this section. Findings related to each subproblems are explained seperately by the help of the tables.

\subsection{Findings Related to First Sub-Problem}

Findings related to prospective teachers' self-efficacy beliefs and attitudes towards the teaching profession are given in the Table 1.

Table-1. Descriptive Analysis of Self-Efficacy Beliefs and Attitudes towards the teaching profession

\begin{tabular}{|c|c|c|}
\hline Factors & $\bar{X}$ & Ss \\
\hline 1.1. Attitudes towards the teaching profession & 4.05 & .65 \\
\hline 2.1. Planning and enhancing learning & 3.42 & .52 \\
\hline 2.2. Creating positive classroom setting & 3.50 & .54 \\
\hline 2.3. Effective learning teaching process & 3.46 & .52 \\
\hline 2.4. Individual differences & 3.36 & .57 \\
\hline 2.5. Academic achievement & 3.35 & .59 \\
\hline 2.6. Total self-efficacy & 3.44 & .49 \\
\hline
\end{tabular}

According to the findings given in Table 1, prospective teachers' attitude scores towards the teaching profession are found as "mostly agree" $(\bar{X}=4.05)$ choice. Also, their self-efficacy belief scores are found as "absolutely belive" $(\bar{X}=3.44)$. When it is analyzed in terms of dimensions the highest score mean is found as 
"creating positive classroom setting" ( $=3.50)$, the lowest score mean is found as "academic achievement" $(\bar{X}$ $=3.35)$.

\subsection{Findings Related to Second Sub-Problem}

Findings related to relationship between the self-efficacy beliefs perceived by prospective teachers and the attitude towards the teaching profession are shown in the Table 2.

Table-2. Correlation Coefficients of the Self-efficacy Beliefs Perceived by Prospective teachers and the Attitude towards the Teaching Profession

\begin{tabular}{l|c|c|c|c|c|c|c}
\hline Dimensions & $\mathbf{1}$ & $\mathbf{2}$ & $\mathbf{3}$ & $\mathbf{4}$ & $\mathbf{5}$ & $\mathbf{6}$ & $\mathbf{7}$ \\
\hline 1. Planning and enhancing learning & - & & & & & & \\
\hline 2. Creating positive classroom setting & $.87^{* *}$ & - & & & & & \\
\hline 3. Effective learning teaching process & $.85^{* *}$ & $.86^{* *}$ & - & & & & \\
\hline 4. Individual differences & $.79^{* *}$ & $.78^{* *}$ & $.78^{* *}$ & - & & & \\
\hline 5. Academic achievement & $.74^{* *}$ & $.74^{* *}$ & $.78^{* *}$ & $.64^{* *}$ & - & & \\
\hline 6. Total self-efficacy & $.95^{* *}$ & $.94^{* *}$ & $.94^{* *}$ & $.86^{* *}$ & $.85^{* *}$ & - & \\
\hline 7. Attitudes towards the teaching profession & $.54^{* *}$ & $.48^{* *}$ & $.48^{* *}$ & $.47^{* *}$ & $.38^{* *}$ & $.53^{* *}$ & - \\
\hline
\end{tabular}

** $\mathrm{p}<.01 ; * \mathrm{p}<.05$

According to the findings given in Table 2 , a positive, moderate and meaningful relationship has been found between the attitude towards the teaching profession and self-efficacy beliefs $(\mathrm{r}=.53, \mathrm{p}<.01)$, planning and enhancing learning $(\mathrm{r}=.54, \mathrm{p}<.01)$, positive classroom setting $(\mathrm{r}=.48, \mathrm{p}<.01)$, effective learning teaching process $(\mathrm{r}=.48, \mathrm{p}<.01)$, individual differences $(\mathrm{r}=.47, \mathrm{p}<.01)$, and academic development $(\mathrm{r}=.38, \mathrm{p}<.01)$. Additionally, it is seen that there is a positive, high level and meaningful relationship between self-efficacy belief and planning and enhancing learning $(\mathrm{r}=.95, \mathrm{p}<.01)$, creating positive classroom setting $(\mathrm{r}=.94, \mathrm{p}<.01)$, effective learning teaching process $(\mathrm{r}=94, \mathrm{p}<.01)$, individual differences $(\mathrm{r}=.86, \mathrm{p}<.01)$, academic achievement $(\mathrm{r}=.85, \mathrm{p}>.01)$. There is a positive, high level and meaningful relationship between self-efficacy belief dimensions planning and enhancing learning with creating positive classroom setting $(\mathrm{r}=.87, \mathrm{p}<.01)$, effective learning teaching process $(\mathrm{r}=.87, \mathrm{p}<.01)$, individual differences $(\mathrm{r}=.79, \mathrm{p}<.01)$, academic achievement $(\mathrm{r}=.74, \mathrm{p}<.01)$. Dimension of positive classroom setting has a high level, meaningful and positive relationship with effective learning teaching process $(\mathrm{r}=.86, \mathrm{p}<.01)$, individual differences $(\mathrm{r}=.78, \mathrm{p}<.01)$, academic achievement $(\mathrm{r}=.74, \mathrm{p}<.01)$. There is a positive, high level and meaningful relationship between effective learning teaching process and individual differences $(\mathrm{r}=.78, \mathrm{p}<.01)$ and academic achievement $(\mathrm{r}=.78, \mathrm{p}<.01)$. A positive, moderate, and significant relationship was found between individual differences and academic achievement $(\mathrm{r}=.64, \mathrm{p}<.01)$.

\subsection{Findings Related to Third Sub-Problem}

Before multiple regression analysis are made, attention is paid to meet the prior conditions. In other words, multiple regression analysis has several assumptions such as multicollinearity, outliers etc. Before performing multiple regression analysis, its assumptions are checked. Sample size is large enough to make multiple regression analysis and multicollinearity is checked. Additionally, in order to check for the outliers, Mahalanobis distances are investigated and outliers are discarded. In order to check multicollinearity, variance inflation factor (VIF) and tolarence value, and CI condition index are checked. After all of these conditions are fulfilled, regression analysis are made.

Regression analysis results related to predicting attitudes towards teaching profession in terms of self-efficacy are given in Table 3 .

Table-3.Regression analysis related to predicting attitudes towards teaching profession in terms of self-efficacy

\begin{tabular}{l|c|c|c|c|c}
\hline Variable & B & Sh & $\boldsymbol{\beta}$ & t & p \\
\hline Constants & 1.679 & .227 & - & 7.386 & .000 \\
\hline Planning and enhancing learning & .490 & .140 & .390 & 3.508 & $.001^{*}$ \\
\hline Creating positive classroom setting & .061 & .136 & .050 & .450 & .653 \\
\hline Effective learning teaching process & .084 & .144 & .066 & .582 & .561 \\
\hline Individual differences & .143 & .098 & .126 & 1.465 & .144 \\
\hline Academic achievement & -.089 & .089 & -.080 & -.993 & .321 \\
\hline
\end{tabular}

As seen in the Table 3, the strength of self-efficacy beliefs in planning and enhancing learning, creating positive classroom setting, effective learning-teaching process, individual differences and academic achievement dimensions together with the prospective teachers' attitudes towards the teaching profession are statistically significant $(\mathrm{R}=.539, \mathrm{p}<.01)$. All dimensions of self-efficacy belief explain $29 \%$ of the total variance in the attitudes of prospective teachers towards the teaching profession. The planning and enhancing learning dimension of selfefficacy belief affects the attitudes of prospective teachers towards the teaching profession in a positive way. Positive classroom setting $(\beta=.050, \mathrm{p}<.05)$, effective learning teaching process $(\beta=.066, \mathrm{p}<.05)$, individual differences $(\beta=.126, p<.05)$, and academic achievement $(\beta=.080, p<.05)$ dimensions are not significant predictors of attitudes towards the teaching profession.

\section{Discussions /Results and Suggestions}

In the present research which is conducted to determine the relationship between prospective teachers' selfefficacy beliefs and their attitudes towards the teaching profession, there are many different results are obtained. According to the result of the research, self-efficacy beliefs of prospective teachers are found at the level of "absolutely believe". When the results are analyzed in terms of dimensions, it is seen that prospective teachers have 
the highest level of self-efficacy in the dimension of creating positive classroom setting while they have lowest level of self-efficacy in the dimension of academic achievement. Bandura (1997) states that teachers who have high level of self-efficacy tend to use different teaching methods and their students' motivation is higher than the other teachers' students. It can be said that prospective teachers strongly believe that they will create a classroom including respect and politeness in which their students study collaborately and participate in the process of learning actively. When the studies conducted on that topic is examined, it can be seen that the results of the present study are parallel with the results of the following studies; Oğuz (2012), Ülper and Bağcr (2012), Şahin and Hciomeroglu (2010), Yilmaz et al. (2010), Yilmaz and Cokluk-Bokeoglu (2008), Kahyaoglu and Yangin (2007). Oğuz (2012) shows that self-efficacy of pre-service class teachers is at the high level and their self-efficacy beliefs show significant differences according to some variables such as age, class level, being a teacher by the help of KPSS. Ülper and Bağcl (2012) find that pre-service Turkish teachers' self-efficacy is at the good level in their research conducted on pre-service Turkish teachers the self-efficacy perception related to teaching profession. (Şahin and Hciomeroglu, 2010) etected that self-efficacy beliefs of the prospective teachers is at the "believe" level and it changes according to educational level. In their research conducted in Nevşehir, Yilmaz et al. (2010) find that self-efficacy of the physical education teacher is at the high level and there is a significant differences between self-efficacy level of them and gender, martial status, environment in which the instution takes place. In their study conducted on self-efficacy beliefs of elemantary school teachers Yilmaz and Cokluk-Bokeoglu (2008) reveal that teaching competence of teachers is at the "absolutely agree" level and their personal competence is at the "agree to some degree" level. In the study conducted on the vocational self-efficacy of elementary school teachers, Kahyaoglu and Yangin (2007) understand that elementary science teachers who are prospective teachers have highest level of self-efficacy. Additionally, there are other studies which don't support the results of the current research. For example, Kutlu and Gökdere (2012) determine that self-efficcacy level of prospective teachers' self efficacy is at the low level by the help of the research conducted on science teachers' attidues and self-efficacy belief level.

Prospective teachers' attitude scores towards the teaching profession are found as "mostly agree" choice. According to these finding, prospective teachers have positive attitudes towards their own professions. Teachers' developing positive attitude towards their own professions has an important effect on performance (Hussain et al., 2011). So, it can be said that positive attitude is important for the teaching process. The fact that students who will be the teacher in the future love their professions and have positive attitude towards this professions is required to be successful teachers. This finding of the research is in parallel with the results of the following researches: Caglar (2013), Özder et al. (2010), Başbay et al. (2009), Bulut (2009), Doğan and Çoban (2009), Güneyli and Aslan (2009), Baykara-Pehlivan (2008), Bedel (2008), Çiçek-Sağlam (2008), Tanel et al. (2007), Terzi and Tezci (2007), Akpinar et al. (2006), Kaya and Büyükkasap (2005), Alsheha (1988) and Al-Houthy (1986). It is revealed that there is a negative attitude towards the teaching profession in the researches conducted on attitudes towards teaching profesion by Kahyaoğlu et al. (2013), Hussain et al. (2011) and Osunde and Izevbigie (2006).

A positive, moderate and meaningful relationship has been found between the attitude towards the teaching profession and self-efficacy beliefs, planning and enhancing learning, creating positive classroom setting, effective learning teaching process, individual differences, and academic achievement. According to this finding, the more self-efficacy of the prospective teachers increases, the more their attitudes towards teaching professionals will be positive. Teachers with high self-efficacy beliefs will have more positive feelings and attitudes towards their profession (Dennis, 2013). In their studies conducted on 336 pre-service primary education teachers studying at Amasya University, Kutlu and Gökdere (2012) find that there is a positive and significant relationship between prospective teachers' attitudes towards science teaching and self-efficacy level. In the study conducted on 366 preservice elemantary teachers studying at Niğde University, Çaycı (2011) reveals that there is positive and significant relationship between teaching competence and attitudes towards teaching profession. In their studies conducted on 380 fourth grader studying at İnönü University, Demirtaş, Cömert and Özer find that there is a positive but low level relationship between prospective teachers' self-efficacy perceptions and attitudes towards profession.

According to another finding of the research, the planning and enhancing learning dimension of self-efficacy belief affects the attitudes of prospective teachers towards the teaching profession in a positive way. Studies have shown that self-efficacy belief predicts various variables; and attitudes towards the teaching profession are predicted by different variables (Çaycı, 2011; Bektaş and Nalçacı, 2012; Caglar, 2013). Self-efficacy is the predictor of academic performance and self-regulated learning. Owens-Twaites (2013). In the study aiming at determining the relationships between prospective teachers' attitudes towards professions and justice perception, (Caglar, 2013) finds that fair learning environment and perceptions related to collaboration based on respect are the predictors of attitudes towards profession. In their studies conducted on 305 prospective teachers studying at Atatürk University, Faculty of Education, Bektaş and Nalçacı (2012) reveal that personal values of the prospective teachers predict their attitudes towards teaching profesion. According to Çaycı (2011) applied teacher training is a significant predictor of self-efficacy beliefs of prospective teachers.

To sum up the results of the research: a) Prospective teachers attitudes towards teaching profession are highly positive. b) Self-efficacy beliefs of prospective teachers are at the high level. c) The highest average score is found in the dimension of creating a positive class environment whereas the lowest average score is found in the academic achievement dimension. d) There is a positive relationship between prospective teachers' attitudes towards teaching profession and their self-efficacy beliefs. e) The planning and enhancing learning dimension of self-efficacy beliefs is a significant predictor of prospective teachers' attitudes towards the teaching profession. In that context, courses that enhance the academic development must be added to the syllabus of the faculty of education and it will increase the prospective teachers' self-efficacy related to academic development. Activities can be organized in order to develop the positive attitudes that necessary for success of prospective teachers and self-efficacy beliefs. These topics which are really important for the teaching professions can be examined in term of pedagogy formation students. 


\section{References}

Akbas, A. and Ö. Çelikkaleli, 2006. Examination of science teachers' self-efficacy beliefs according to gender, learning type and universities. Mersin University Journal of Education, 2(1): 98-110.

Akkoyunlu, B. and S. Kurbanoglu, 2003. Pre-service teachers' perceptions of information literacy and computer self-efficacy. Hacettepe University Faculty of Education Journal, 24: 1-10.

Akpinar, E., E. Yildiz and O. Ergin, 2006. Attitudes of science teacher candidates towards teaching profession. Buca Education Faculty Journal, 19: 56-62

Aksou, V., K. Yüksel, İ.H. Diken and Ö. Karaaslan, 2012. Self-efficacy perceptions of guidance teachers about psychological counseling and guidance in special education. Journal of Pamukkale University Education Faculty, 31(31): 137-148.

Al-Houthy, I.M., 1986. A study of factors influencing secondary school students' career choice and their attitudes toward the teaching profession. The Case of the Yemen Arab Republic. Unpublished Doctoral Dissertation. The Florida State University.

Alsheha, F.A., 1988. A study of male college of education students' attitude toward the teaching profession in the Kingdom of Saudi Arabia. Unpublished Doctoral Dissertation, The Florida State University.

Altuncekic, A., S. Yaman and O. Koray, 2005. A study on self-efficacy belief levels and problem solving skills of candidate students (The Kastamonu Province Case). Kastamonu Univ. Kastamonu Educ. J, 13(1): 93-102.

Aşkar, P. and M. Erden, 1986. Attitudes of teacher candidates towards teaching profession. Marmara University, 1: 24-30.

Aşkar, P. and A. Umay, 2001. Computer-related self-efficacy beliefs of primary school teachers. Hacettepe University Faculty of Education Journal, 2 1: 1-8.

Aslan, R.A.D. and A.K. Ayol, 2006. The attitudes of primary teacher candidates for teaching profession. Cukurova University Journal of Institute of Social Sciences, 15(2): 51-60.

Aydiner, B.B., 2011. General self-efficacy of the sub-dimensions of life goals of university students, life satisfaction and examination by various variables. Unpublished Master's Thesis, Sakarya University, Institute of Educational Sciences, Sakarya.

Azar, A., 2010. Self-efficacy beliefs of secondary school science and mathematics teacher candidates. ZKU Journal of Social Sciences, 6(12): 235-252.

Bandura, A., 1982. Self-efficacy mechanism in human agency. American Psychologist, 37(2): 122-147.Available at: https://doi.org/10.1037//0003-066x.37.2.122.

Bandura, A., 1997. Self-efficacy: The exercise of control. New York: Freeman.

Başbay, M., G. Ünver and N.T. Bümen, 2009. Attitudes of non-thesis graduate students in secondary education field towards the teaching profession: A longitudinal study. Educational Administration in Theory and Practice, 59(59): 345-366.

Baykara-Pehlivan, K., 2008. A study on the socio-cultural characteristics of primary school teacher candidates and their attitudes towards teaching profession. Mersin University Faculty of Education Journal, 4(2): 151-168.

Bedel, E.F., 2008. Interactions among attitudes toward teaching and personality constructs in early childhood pre-service teachers. Online Submission, 4(1): 31-48.

Bektaș, F. and A. Nalçacı, 2012. The relationship between personal values and attitude towards teaching profession. Educational Sciences: Theory\&Practice, 12(2): 1244-1248.

Bulut, H. and Ç. Doğar, 2006. Examining the teacher candidates' attitudes towards the teaching profession. Journal of Erzincan Faculty of Education, 8(1): 13-27.

Bulut, İ., 2009. Evaluation of teacher candidates' attitudes concerning teaching profession (Dicle and Firat University Sample). Journal of Dicle University, Ziya Gökalp Education Faculty, 14: 13-24.

Caglar, C., 2013. The relationship between the levels of alienation of the education faculty students and their attitudes towards the teaching profession. Educational Sciences: Theory and Practice, 13(3): 1507-1513.

Çakır, Ö., A. Kan and Ö. Sünbül, 2006. Evaluation of teaching profession and non-thesis master programs in terms of attitude and selfefficacy. Mersin University Faculty of Education Journal, 2(1): 36-47.

Çakiroglu, J., E. Çakiroglu and W.J. Boone, 2005. Pre-service teacher self-efficacy beliefs regarding science teaching: A comparison of preservice teachers in Turkey and the USA. Science Educator, 14(1): 31-40.

Can, Ş., 2010. Attitudes of non-thesis students towards teaching profession. Mugla University Institute of Social Sciences Journal, $24:$ 13-28.

Çapri, B. and Ö. Çelikkaleli, 2008. Examination of teacher candidates' attitudes and professional proficiency beliefs according to gender, program and faculties. Inonu University Faculty of Education Journal, 9(15): 33-53.

Çaycı, B., 2011. The relationship between the elementary prospective teachers' teacher efficacy and their attitudes towards the profession of teaching. Education, 132(2): 402-418.

Celep, C., 2000. The correlation of the factors: The prospective teachers' sense of efficacy and belief, and attitudes about student control. National FORUM of Educational Administration and Supervision Journal, 17(4): 99-1 12.

Çetinkaya, Z., 2009. Determining the attitudes of turkish teacher candidates towards the teaching profession. Primary School Online, 8(2): $298-305$.

Çiçek-Sağlam, A., 2008. Attitudes of teaching music students towards teaching profession. Journal of Yüzüncü Yıl University Faculty of Education, 5(1): 59-69.

Coşkun, M., 2011. Attitudes of religious culture teachers towards the teaching profession: Comparative analysis. EKEV Academy Magazine, 15(48): 269-279.

Dellinger, A.B., J.J. Bobbett, D.F. Olivier and C.D. Ellett, 2008. Measuring teachers' self-efficacy beliefs: Development and use of the tebsself. Teaching and Teacher Education, 24(3): 751-766.Available at: https://doi.org/10.1016/j.tate.2007.02.010.

Demirtas, H., M. Comert and N. Ozer, 2011. Pre-service teachers' self-efficacy beliefs and attitudes towards profession. Egitim Ve BilimEducation and Science, 36(159): 96-111.

Dennis, L.M.G., 2013. Multiplication achievement and self-efficacy in third- and fifth-grade students: Effects of cross-age peer tutoring and skill training. Unpublished Doctoral Dissertation, The University of Arizona.

Doğan, T. and A.E. Çoban, 2009. Examining the relationship between the attitudes of the faculty of education and the attitudes towards teaching profession. Education and Science, 34(153): 157-168.

Ekici, G., 2008. The effect of classroom management course on teacher self-efficacy perception of teacher candidates. Hacettepe University Faculty of Education Journal, 35: 98-110.

Eryenen, G., 2008. The target orientations of teacher candidates, the relationship between academic and teaching self-efficacy and the role of these variables in predicting academic achievement. (Unpublished Master's Thesis). Istanbul University, Institute of Social Sciences, Istanbul.

Güneyli, A. and C. Aslan, 2009. Evaluation of Turkish prospective teachers' attitudes towards teaching profession (Near East University case). Procedia-Social and Behavioral Sciences, 1(1): 313-319.Available at: https://doi.org/10.1016/j.sbspro.2009.01.059.

Gürbüztürk, O. and S.Z. Genç, 2004. Teachers' views on the teaching profession. Inonu University Faculty of Education Journal, 5(7): 47-62.

Gürol, A., S. Altunbaş and N. Karaaslan, 2010. A study on pre-service teachers' self-efficacy beliefs and epistemological beliefs. E-Journal of New World Sciences Academy, 5(3): 1395-1404.

Hussain, S., R. Ali, M.S. Khan, M. Ramzan and M.Z. Qadeer, 2011. Attitude of secondary school teachers towards teaching profession. International Journal of Academic Research, 3(1): 985-990.

Işık, S., M. Yaman and H. Soran, 2005. Determining the types of biology teacher candidates according to their attitudes towards biology and biology teaching. Hacettepe University Faculty of Education Journal, 29: 110-116.

Kahyaoğlu, M., Ç. Tan and M.F. Kaya, 2013. Learning styles of primary school teachers and their attitudes towards teaching profession /pre-service teachers' learning styles and attitude towards teaching profession. Mustafa Kemal University Journal of Institute of Social Sciences, $10(21): 225-236$.

Kahyaoglu, M. and S. Yangin, 2007. Views of prospective teachers in elementary school teaching departments about professional selfefficacy. Kastamonu Education Journal, 15(1): 73-84. 
Karadağ, R., 2012. The attitudes of Turkish teacher candidates to teaching profession and choice of preferences. Humanities Sciences, 7(2): 44-66.

Kaya, B. and E. Büyükkasap, 2005. Profiles of physics teacher program students, attitudes and concerns about teaching profession. Gazi University Education Journal, 13(2): 367-380.

Kemer, G., 2006. The role of self-efficacy, hope, and anxiety in predicting university entrance examination scores of eleventh-grade students. Unpublished Master Thesis, Middle East Technical University, Ankara.

Külekçi, G., 2011. A study on pre-service English teachers' self-efficacy beliefs depending on some variables. International Online Journal of Educational Sciences, 3(1): 245-260.

Kutlu, N. and M. Gökdere, 2012. Examining teacher candidates' attitudes towards science teaching and self-efficacy belief levels. X. National Sciences http: // congress. In niger. Edu. tr / xufbmek (17.04. 2013). training.

Lin, Y.-H. and J.-C. Liang, 2012. Preschool teachers' internet attitude and their internet self efficacy: A comparative study between preservice and in-service teachers in Taiwan. IIAI International Conference on Advanced Applied Informatics. pp: $334-339$.

Morgil, I., N. Seçken and A.S. Yucel, 2004. Examination of self-efficacy beliefs of chemistry teacher candidates in terms of some variables. Balıkesir University Journal of Institute of Science and Technology, 6(1): 62-72.

Oğuz, A., 2012. Academic self-efficacy beliefs of prospective primary school teachers. Anadolu Journal of Educational Sciences International, 2(2): 15-28.

Oguz, A. and N. Topkaya, 2008. Teachers' self-efficacy beliefs and their attitudes towards secondary education. Academic Perspective, 14: $23-36$.

Öksüzoğlu, P., 2009. The competence perceptions of pre-service teacher candidates on the teaching profession. (Unpublished Master's Thesis). Mersin University, Institute of Social Sciences, Mersin.

Open, S. and A. Kolomuç, 2012. Examining the attitudes of the teacher candidates towards the teaching profession. Journal of Education and Teaching Research, 1(2): 266-271.

Oral, B., 2004. Attitudes of teaching faculty students towards teaching profession. Journal of Educational Research, 15(4): 88-98.

Osunde, A.U. and T.U. Izevbigie, 2006. An assessment of teachers' attitude towards teaching profession in Midwestern Nigeria. Education, 126(3): 462-467.

Owens-Twaites, L., 2013. The effects of staff development on teacher self-efficacy and student achievement in an elementary inclusion program. ProQuest LLC.

Özbek, R., M. Kahyaoğlu and N. Özgen, 2007. Evaluation of teacher candidates' views on teaching profession. Journal of Social Sciences, 9(2): $221-232$.

Özdemir, S.M., 2008. Examining the self-efficacy beliefs of the teacher candidates in terms of various variables. Journal of Educational Administration in Theory and Practice, 14(2): 277-306.

Özder, H., G. Konedra and C.P. Zeki, 2010. Examining the pre-service teachers' attitudes towards teaching profession in terms of various variables. Educational Administration in Theory and Practice, 16(2): 253-275.

Özenoğlu-Kiremit, H., 2006. Comparison of biology-related self-efficacy beliefs of science teaching students. (Unpublished Doctoral Dissertation). Dokuz Eylül University, Institute of Educational Sciences, İzmir.

Özkan, H.H., 2012. Examination of the teacher candidates' attitudes towards teaching profession in the teaching formation program (Case of SDU). Ahi Evran University Kırşehir Education Faculty Journal, 13(2): 29-48.

Ready-Bıkmaz, F., 2006. Self-efficacy beliefs in science teaching and opinions about effective science course. Educational Research, 6(25): 3444.

Saban, A., İ. Korkmaz and S. Akbaşlı, 2004. Vocational concerns of prospective teachers. Journal of Educational Research, 17: 198-209.

Şahin, E., 2010. The effect of primary school teachers' teaching style preferences, gender, professional seniority, self-efficacy perception and self-efficacy learning preparedness levels on professional competencies. YTU Social Sciences Institute.

Şahin, T.Ç. and S. Hciomeroglu, 2010. Teaching efficacy adaption of belief scale to Turkish and quality believe. Journal of Dokuz Eylül University, Buca Education Faculty, 27: 63-75.

Savran, A. and J. Çakıroğlu, 2001. Biology teacher candidates' self-efficacy beliefs about biology teaching. Journal of Hacettepe University Faculty of Education, 21: 105-112.

Smolleck, L.A. and A.M. Mongan, 2011. Changes in preservice teachers' self-efficacy: From science methods to student teaching. Journal of Educational and Developmental Psychology, 1(1): 133.Available at: https://doi.org/10.5539/jedp.v1n1p133.

Soprano, K. and L.-L. Yang, 2012. Inquiring into my science teaching through action research: A case study on one pre-service teacher's inquiry-based science teaching and self-efficacy. International Journal of Science and Mathematics Education, 11(6): 13511368.Available at: https://doi.org/10.1007/s10763-012-9380-x.

Tanel, R., S. Kaya-Şengören and Z. Tanel, 2007. Related to Teaching Profession of Teachers of Physics. Journal of Pamukkale University Education Faculty, 22(22): 1-9.

Taskin, Ç. and S. Hciomeroglu, 2010. Teaching efficacy adaption of belief scale to Turkish and quality believe. Journal of Dokuz Eylül University, Buca Education Faculty, 27: 63-75.

Tekerek, M. and S. Polat, 2011. Teachers' attitudes towards teaching profession. 5th International Computer \& Instructional Technologies Symposium, 22-24 September 2011 , Firat University, Elazığ, Turkey.

Temizkan, M., 2008. A study on Turkish teachers' attitudes towards teaching profession. Turkish Journal of Educational Sciences, 6(3): 461486.

Terzi, A.R. and E. Tezci, 2007. Attitudes of necatibey education faculty students towards teaching profession. Educational Administration in Theory and Practice, 52: 593-614.

True, C., M. Yilmaz, P. Koseoglu and H. Soran, 2006. Self-efficacy beliefs in teaching biology education. Ankara University Journal of Faculty of Educational Sciences, 39(1): 57.

Ülper, H. and H. Bağcl, 2012. Self-efficacy perceptions of Turkish teacher candidates towards teaching profession. Turkish Studies, 7(2): $1115-1131$.

Usluel, Y.K., 2006. Comparison of teacher candidates and teachers' information literacy self-efficacy. Educational Research, 6(22): 233-243.

Üstüner, M., 2006. Validity and reliability study of attitude scale for teaching profession. Educational Administration in Theory and Practice, 45(45): 109-127.

Üstüner, M., H. Demirtas and M. Cömert, 2009. The attitudes of prospective teachers towards the profession of teaching (The case of Inonu University, Faculty of Education). Education and Science, 34(151-155): 140.

Uysal, İ. and S. Kösemen, 2013. Examination of general self-efficacy beliefs of teacher candidates. Journal of Education and Teaching Research, 2(2): $217-226$.

Yildirim, F. and İ.Ö. İlhan, 2010. Validity and reliability study of the turkish self-efficacy scale turkish form. Turkish Journal of Psychiatry, 21(4): 301-308.

Yilmaz, E., R. Yigit and İ. Kasarci, 2012. Academic success of primary school students and some changes in terms of some variables. Mehmet Akif Ersoy University Faculty of Education Journal, 1(23): 371-388.

Yilmaz, G., B. Yilmaz and N. Turk, 2010. Examination of self-efficacy levels of physical education and sports teachers about their professions (Case of Nevşehir Province). Selcuk University, Journal of Physical Education and Sport Science, 12(2): 85-90.

Yilmaz, K. and O. Cokluk-Bokeoglu, 2008. Primary school teachers' belief of efficacy. Ankara University Journal of Education Faculty, 41(2): 143-167. 